\title{
New record of Corchorus hirtus L. in Piauí, Brazil
}

\author{
Antonia Alikaene de Sáa®, Antônio Reis de Sousab®, Maria Carolina de Abreuc*®, \\ Francisco Soares Santos Filho a,b® \\ a Universidade Federal do Piauí, Teresina, 64049-550, Piauí, Brasil.*allyknsa@hotmail.com \\ b Programa de Pós-Graduação em Desenvolvimento e Meio Ambiente,Universidade Federal do Piauí, \\ Teresina, 64049-550, Piauí, Brasil. \\ c Programa de Pós-Graduação em Biodiversidade e Conservação, Universidade Federal do Piauí, Floriano, \\ Teresina, 64808-605, Piauí, Brasil.
}

Received: July 11, 2021 / Accepted: August 2, 2021 / Published online: September 30, 2021

\begin{abstract}
Corchorus hirtus L. belongs to the Malvaceae family, it is commonly found in humid and ruderal environments. The occurrence of this species is recorded in all states of Northeast Brazil, except Piauí. Therefore, the aim of this work is to record the occurrence of the species in an area of Piauí, collected in the county of Oeiras, Riacho Mocha, a region of ecological tension. To portray the geographic distribution of the plant, there were made a morphological characterization with pictures of relevant aspects of the plant's morphology.
\end{abstract}

Keywords: Floristic richness, geographical distribution, Malvaceae, transition vegetation.

\section{Nova ocorrência de Corchorus hirtus L. para o Piauí, Brasil}

\begin{abstract}
Resumo
Corchorus hirtus L. pertence à família Malvaceae, é comumente encontrado em ambientes úmidos e ruderais. A ocorrência desta espécie é registrada em todos os estados do Nordeste do Brasil, exceto Piauí. Portanto, o objetivo deste trabalho é registrar a ocorrência da espécie em uma área do Piauí, coletada no município de Oeiras, Riacho Mocha, uma região de tensão ecológica. Para retratar a distribuição geográfica da planta, foi feita uma caracterização morfológica com fotos de aspectos relevantes da morfologia da planta.
\end{abstract}

Palavras-chave: Riqueza florística, distribuição geográfica, Malvaceae, vegetação de transição.

Floristic studies are important for the knowledge of the biological diversity and geographic distribution of species (Souza, Coutinho, Silva, Amorim \& Alves, 2017; Vasconcelos et al., 2017). The Malvaceae Juss. family has a wide geographic distribution with approximately 4.200 species belonging to 250 genera, mainly distributed in the tropical regions of the planet (Mattos, Ferreira, Bovini \& Nadruz, 2019). It is subdivided into nine subfamilies, including Grewioideae, which comprises approximately 25 genera and 700 species, in Brazil, this subfamily is represented by nine genera and approximately 60 species (Souza, Monteiro \& Melo, 2020). Species are distributed in all Brazilian regions and phytogeographic domains (Fernandes-Júnior, 2020) which can be found in preserved environments, degraded areas, humid environments, margins of water bodies and they can even be considered aquatic macrophytes (Lima, Lima, SoaresJúnior, Pimentel \& Zickel, 2010).

The genus Corchorus L. is represented by species of herbaceous habit, with approximately 100 species and cosmopolitan distribution, mainly in the tropics. In Brazil, species for the genus are found, occurring in all regions in the domains of the Amazon, Caatinga, Cerrado, Atlantic Forest and Pantanal, including anthropized areas and galleries (Fernandes-Júnior, 2020).

The state of Piauí in northeastern Brazil covers an area of $251,756.515 \mathrm{~km}^{2}$ (IBGE (full name for this abbreviated), 2020). The vegetal formations of the state are the Caatinga with approximately $49.6 \%(12,478,363$ hectares $)$ and the Cerrado approximately $47 \%$, of this, $33 \%$ corresponds to the domain area $(8,349,759$ hectares $)$ and $14 \%(3,507,107$ hectares) in transition areas. The remainder, less than $3 \%$ (738,156 hectares) corresponds to "transition forests" with high biodiversity and are significantly heterogeneous, where there are species from several floristic domains such as the Amazon, Cerrado, Caatinga and Mata Atlântica (Castro, 2020).

This study brings the first record of Corchorus hirtus L. for Piauí. Therefore, the aim was to register the first occurrence of this species in the state, as well as to carry out a brief morphological and photographic description, in order to expand knowledge about the species and its geographic distribution. 
The area of the species occurrence was the county of Oeiras, Piauí, Northeastern Brazil, in a stream (Riacho Mocha), humid and anthropized, with geographical coordinates $7^{\circ}$ 0'2.49 "S and $42^{\circ} 8^{\prime} 5.0 " \mathrm{~W}$, at $190 \mathrm{~m}$ above the sea level, a place belonging to the Cerrado Caatinga transition vegetation.

The county of Oeiras comprises an area of 2,702,486 km², and belongs to the Picos microregion, a semi-arid region of the state, with transition Cerrado Caatinga vegetation (IBGE, 2020). The climate is warm semi-arid tropical according to the Köppen classification (Aw), with a dry period of seven to eight months, the climatic averages vary during the year from $22{ }^{\circ} \mathrm{C}$ to $37{ }^{\circ} \mathrm{C}$ (Climatempo, 2020). The main types of soils are dystrophic red-yellow latosols associated with dystrophic litholic soils, dystrophic quartz sands and indiscriminate tropical concessionary soils.

The collection was carried out in May 2019, by means of an expedition to the field for botanical collection referring to the Master's degree project of the first author (Revisit to the Spix and Martius Expedition in Piauí), where specimens were collected from all botanical families, in reproductive state. The species is registered in the electronic system of SisGen National System for the Management of Genetic Heritage and Associated Traditional Knowledge under the number A53B413.

The species was processed according to usual botanical techniques (Mori, Silva \& Lisboa, 1989), identified based on a specialized literature review (Tschá, Sales \& Esteves, 2002; Colmenero-Robles et al., 2010; Lima, Bovini \& Conceicao, 2019), identification key and confirmed with specialist as well as digital collections available in Reflora (http://reflora.jbrj.gov.br), (http://www.splink.org.br/) and $\begin{aligned} & \text { Species } \\ & \text { Powo }\end{aligned}$ Link (http://www.plantsoftheworldonline.org/).

For the descriptions of general morphological characters, specialized bibliographies were consulted (Colmenero-Robles et al., 2010; Lima et al., 2019) and complemented with information on the analysis of botanical material, exclusive characteristics species, geographic distribution, flowering and fruiting periods, obtained from online data networks Flora do Brasil $2020 \quad$ (http://floradobrasil.jbrj.gov.br/reflora/), Tropicos.org (http://www.tropicos.org), Species Link (http://www.splink.org.br/). The exsiccate of the new record was incorporated into the Delta do Parnaíba Herbarium (HDELTA6603), from the Universidade Federal do Delta do Parnaíba (UFDPar).

New records: Brazil - Piauí - Oeiras, Riacho Mocha; $7^{\circ}$ 0'2.49 "S $42{ }^{\circ}$ 8'5.0" W; 190 m alt.; 25.VI.2020; collection A. A. Sá, no 110, HDELTA6603.

Identification: Corchorus hirtus L., sub-shrub $40 \mathrm{~cm}$ high (Figure 1.A); cylindrical branches, pubescent to glabrescent, sparse simple trichomes and a dense longitudinal line, trichomes; stipules 0.1-1.5 mm long, linear, trichomes equal to branches. Whole leaves, alternating spirals; petiole $0.1-1.5 \mathrm{~cm}$ long, pubescent; leaf blade $0.6-5.8 \times 0.9-2.3 \mathrm{~cm}$, ovate to elliptical-lanceolate, green, discolored, membranous, obtuse to rounded base, acute apex, serrated margin (Figure 1.B), both hairy surfaces, sparse simple trichomes. Inflorescence, with 2 flowers, axillary or terminal (Figure 1.C), pedicels 9-10 mm long; flat sepals 8-10 mm long, oblong, acuminated apex, externally with simple trichomes, internally glabrous; $8 \times 2.5-$ $3 \mathrm{~mm}$ petals, obovate, yellow, glabrous; absent staminodes, short androgynophore, without glands, stamens 48, 6-7 mm long, free; ovary $2-3 \times 0.8-1 \mathrm{~mm}$, cylindrical to elliptical, 4 locules, numerous eggs per locule; styles $5 \mathrm{~mm}$ long, capitulated stigmas. Capsule $1.8-3.9 \times 0.2-0.3 \mathrm{~cm}$ (Figure 1 . F), elongated-flattened, longitudinal dehiscence, hirsute, with simple trichomes (Figure 1.D); seeds c. $1.2 \times 1 \mathrm{~mm}$, tetragonal, blackish, wingless, glabrous (Figure 1.E).

The species Corchorus hirtus L. is a pantropical plant that occurs in different environments. It is usually found in ruderal environments (Lara, Macedo \& Brandão, 2003) but it also occurs in humid environments, appearing in floristic lists of aquatic macrophytes (Lima et al., 2010; Torres, Fernando \& Lucena, 2016). In this research, it was collected in a stream (Riacho Mocha), within the urban perimeter of the county of Oeiras - PI and can, therefore, be classified as an aquatic macrophyte (humid environment), as well as a ruderal plant (anthropized environment).

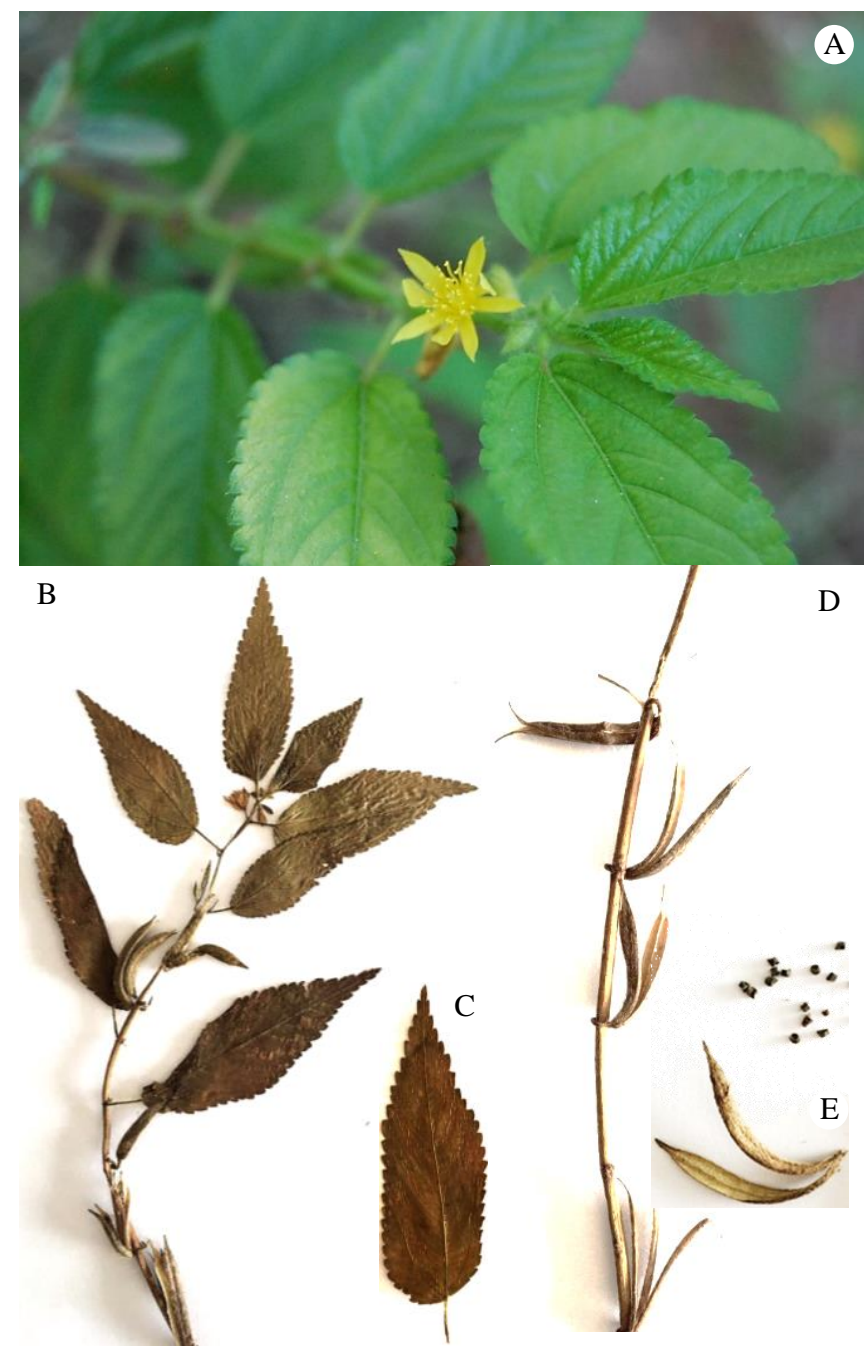

Figure 1. Corchorus hirtus L.: flower (A), reproductive branch (B), leaf (C), Fruits showing the insertion and the apex of the fruit (D). fruit showing dehiscence by two valves and Seeds (E). Photographs: Authors, 2019.

The genus Corchorus L. it is distributed throughout the tropical and subtropical regions of the world. (Souza \& Esteves, 2002; Sinha, Kar, Ramasubramanian, Kundu \& Mahapatra, 2011), six species of Corchorus L. are registered 
in Brazil, Corchorus aestuans L., Corchorus argutus Kunth, Corchorus capsularis L., C. hirtus L., Corchorus olitorius L. and Corchorus orinocensis Kunth (Fernandes-Júnior, 2020). For the state of Piauí, researchers have identified, so far, only four species of the genus Corchorus L., with two occurrences of $C$. aestuan L. in the counties of São João do Piauí and Teresina, one record of $C$. argutus L. in the county of Floriano (INCT, 2021) and C. olitorius L. in a floristic survey of ruderal plants in the county of Picos, Piauí (Sousa et al., 2020).

In the study area, the species C. hirtus L. was recorded, linked to the transition area Caatinga and Cerrado, being, therefore, the fifth record of the genus for the state, showing that the studies of floristic surveys in Piauí, especially in the semiarid, are demonstrating an expressive biodiversity to be still discovered.
Corchorus hirtus L. is an herbaceous native America species (Colmenero-Robles, Gual-Díaz \& Fernández-Nava, 2010) which presents flowers and fruits throughout the year, widely distributed in tropical regions (Souza \& Esteves, 2002). This species is similar to C. argutus, mainly because they share the type of habit and the floral morphology (Souza et al., 2020).

The six species of the genus Chorchorus that occur in Brazil can be distinguished mainly by characters related to the indumento of the branches, presence of appendages on the leaves, number of stamens, shape of the capsules and seeds. We present an identification key for species occurring in Brazil produced based on data from the descriptions available in Flora do Brasil 2020.

\section{Identification key for species of the genus Chorchorus in Brazil}

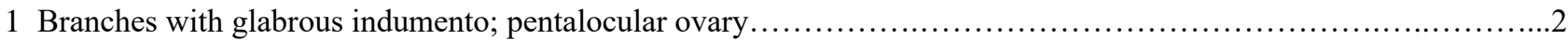

1' Branches with simple or simple glandular trichomes; biocular, trilocular or tetralocular ovaries........................... 3

2 Stem disc evident; globe capsule C. capsularis

2' Stem disc not evident; cylindrical capsule..... C. olitorius

3 Appendices at the bases of the present sheets; evident stem disc. C. aestuans

3' Appendices at bases of missing sheets; stem disc not evident. ........4

4 Branches with simple glandular trichomes; cubic seeds.

4' Branches with simple trichomes; angled sub-rotunda seeds

5 Oblanceolate petals; cylindrical capsules.

C. orinocensis

5' Angled petals; cylindrical capsules compress.

C. argutus

It is believed that there is still a remarkably large gap in relation to the biodiversity that actually occurs in Piauí and that further studies on flora are needed for the state. Therefore, this work brings scientific contributions to expand the knowledge of the geographical distribution of this species and the floristic richness of the state of Piauí, as well as to assist taxonomic studies on local biodiversity, especially on C. hirtus L. (Malvaceae), which will be recorded and documented in this article and in the collections and database of the Herbário Delta do Parnaíba and digital herbariums to assist future works on the biodiversity of Piauí.

\section{Acknowledgments}

We gratefully thank the herbarium curator of Herbário Delta do Parnaíba for the support and the specialist Aurelio Colmenero Robles for the contribution given in confirming the identification of the species.

\section{References}

Castro, A. A. J. F. (2020). Mata atlântica no Piauí: isto é, ou não é uma "fake news"? Publicações avulsas em conservação de ecossistemas, 34, 1-18, 2020.

Climatempo. (2020). https://www.climatempo.com.br/previsao-dotempo/cidade/2669/oeiras-pi.

Colmenero-Robles, J. A., Gual-Díaz, M., \& Fernández-Nava, R. (2010). El género Corchorus (Tiliaceae) en México. Polibotánica, (29): 29-65.

Fernandes-Júnior, A. J. (2020). Corchorus in Flora do Brasil 2020. Jardim Botânico do Rio de Janeiro. http://floradobrasil.jbrj.gov.br/reflora/floradobrasil/FB9042

Flora do Brasil. (2020) Jardim Botânico do Rio de Janeiro. http://floradobrasil.jbrj.gov.br/reflora/

IBGE (Instituto Brasileiro de Geografia e Estatistica). (2020). Área da unidade territorial: Área territorial brasileira. Rio de Janeiro: IBGE.
INCT (Herbário Virtual da Flora e dos Fungos). Rede Species Link.

Lara, J. F. R., Macedo, J. F., \& Brandão, M. (2003). Plantas daninhas em pastagens de várzeas no Estado de Minas Gerais. Planta Daninha, 21(1), 11-20. doi: 10.1590/S0100-83582003000100002

Lima, J. B., Bovini, M. G., \& Conceicao, A. S. (2019). Bombacoideae, Byttnerioideae, Grewioideae and Helicterioideae (Malvaceae s.1.) in the Raso da Catarina Ecoregion, Bahia, Brazil. Biota Neotropica, 19(3), e 20180569. doi: 10.1590/1676-0611-bn-2018-0569

Lima, L. F., Lima. P. B., Soares-Júnior, R. C., Pimentel, R. M. M., \& Zickel, C. S. (2010). Diversidade de macrófitas aquáticas no estado de Pernambuco: levantamento em herbário. Revista de Geografia, 26 (3), 307-319. doi: 10.51359/2238-6211.2009.228782

Mattos, J. R., Ferreira, C. D. M., Bovini, M. G., \& Nadruz, M. (2019). Malvaceae, cultivada no arboreto do Jardim Botânico do Rio de Janeiro: a família do hibisco. (1. ed.) Vertente edições, Rio de Janeiro, Brasil, $69 \mathrm{p}$.

Mori, S. A., Silva, L. A. M., Lisboa, G. C. L. (1989). Manual de manejo do herbário fanerogâmico. (2. ed.), Ilhéus, Bahia, 104p.

POWO (2019) Plants of the world online. Royal Botanic Gardens, Kew.

Sinha, M. K., Kar, C. S., Ramasubramanian, T., Kundu, A., \& Mahapatra, B.S. (2011). Corchorus. In: Kole C. (eds) Wild Crop Relatives: Genomic and Breeding Resources. Springer, Berlin, Heidelberg. doi: 10.1007/978-3-642-21102-7_2

Sousa, A. R., Deus, M. S. M., Chaves, T. P., Abreu, M. C., Borges, K. M. L., Araújo, A. M., Nascimento, F. B. (2020). Composição Florística de Plantas Ruderais em uma área do Semiárido Nordestino. In: Renato Abreu Lima. (Org.). Avanços e atualidade na botânica brasileira. $\left(1^{\mathrm{a}}\right.$ ed.), Stricto Sensu, Rio Branco, p. 91-108.

Souza, B. M., \& Esteves, G. L. (2002) Tiliaceae. In: Wanderley, M. G. L., Shepherd, G. J., Giulietti, A. M., Melhem, T. S., Bittrich, V. E., Kameyama, C. (eds.), Flora Fanerogâmica do Estado de São Paulo, São Paulo, v. 2, pp. 331-342.

Souza, S. M., Monteiro, F. K. S., \& Melo, J. I. M. (2020). Grewioideae Dippel (Malvaceae) no Estado da Paraíba, Brasil. Hoehnea, 47: e122019. doi: 10.1590/2236-8906-12/2019

Souza, M. P., Coutinho, J. M. D. C. P., da Silva, L. S., Amorim, F. S., \& Alves, A. R. (2017). Composição e estrutura da vegetação de caatinga no sul do Piauí, Brasil. Revista Verde de Agroecologia e Desenvolvimento Sustentável, 12(2), 210-217. doi: 
10.18378/rvads.v12i2.4588

Torres, C. R. M., Fernando, E. M., Lucena, M. F. (2016). Checklist de plantas aquáticas em trechos de caatinga do semiárido paraibano, Nordeste do Brasil. Gaia Scientia, 10, 284-296. doi: 10.21707/gs.v10.n04a23

Tropicos.org. Missouri Botanical Garden.

Tschá, M. D. C., Sales, M. F., \& Esteves, G. L. (2002). Tiliaceae Juss. no estado de Pernambuco, Brasil. Hoehnea, 29 (1): 1-18.

Vasconcelos, A. D. M., Henriques, I. G. N., de Souza, M. P., de Sousa Santos, W., de Sousa Santos, W., , \& Ramos, G. G. (2017). Caracterização florística e fitossociológica em área de Caatinga para fins de manejo florestal no município de São Francisco-PI. Agropecuária Científica no Semiárido, 13(4), 329-337. doi: 10.30969/acsa.v13i4.967

License: Creative Commons CC BY NC 4.0 